Acta Veterinaria (Beograd), Vol. 61, No. 5-6, 653-662, 2011.

DOI: 10.2298/AVB1106653Z

UDK 616.314.13:599.742.73

\title{
IDENTIFYING ENAMEL DIFFUSION PROPERTIES IN FELINE TEETH AFFECTED WITH RESORPTIVE LESIONS
}

ŽIVKOVIĆ R, TODOROVIĆ A, TIHAČEK ŠOJIĆ LJILJANA and MILIĆ LEMIĆ ALEKSANDRA

University of Belgrade, School of Dentistry, Clinic for Prosthetic Dentistry, Serbia

(Received 10 th June 2011)

Various factors have been suggested in the pathogenesis of feline resorptive lesions, such as periodontal disease, dietary factors, mechanical stress, developmental tooth defects, breed and viral disease, although none of these factors have been definitively proven to be the direct cause. It was recently published that normally enamel in cats is significantly thinner at the cemento-enamel junction, and both enamel and dentine are significantly less mineralized than elsewhere on the tooth. However, it is still unclear what anatomical features of the tooth surface are associated with a predisposition for resorptive lesions, and what is the initiating cause for the clastic activity afterwards.

The present study was undertaken with the aim to describe enamel properties of transport and distribution of organic molecules in intact feline teeth and teeth affected with resorptive lesions.

The results indicate that damaged enamel is prone to a greater bilateral diffusion process, leading to continuous disruption of the enamel structure. Also, teeth that are subjected to occlusal stress are at greater risk of destruction because micro fractures produce disarrangements in feline dental tissue diffusion homeostasis. The relationship between these features with feline dental resorptive lesions requires further studies.

Kew words: enamel, diffusion, resorption

\section{INTRODUCTION}

Feline odontoclastic resorptive lesions affect more than one third of all adult domestic cats and continue to be an enigma in veterinary dental science. Various factors have been suggested in the pathogenesis of these lesions, such as periodontal disease, dietary factors, mechanical stress, developmental tooth defects, breed and viral disease, although none of these factors have been definitively proven to be the direct cause of tooth resorptive lesions (Reiter and Mendoza, 2002; von Arx et al., 2009; Zivkovic et al., 2010). Feline odontoclastic resorptive lesions affect multiple teeth but are more frequently observed on molar and premolar teeth than on the canines and incisor teeth. The buccal and labial 
surfaces are more often affected compared with the lingual surfaces (Reiter and Mendoza, 2002, Roux et al., 2005). In addition, these lesions are often symmetrical and therefore do not seem to occur at random (Ingham et al., 2001), which suggests that there is a predilection site on different tooth regions. Many early studies of feline resorptive lesions described lesions as starting at the cemento-enamel junction (i.e. neck or cervical lesions) (Schneck and Osborn. 1976; Schlup and Stich, 1982; Reichart et al., 1984), while more recent analyses suggest that resorptive lesions may initiate anywhere on the tooth surface (Harvey et al., 2004; DeLaurier et al., 2009). DeLaurier et al. (2006) in their morphological study of the normal cat teeth described that enamel is significantly thinner at the cemento-enamel junction, and both enamel and dentine are significantly less mineralized than elsewhere on the tooth. However, it is still unclear what anatomical features of the tooth surface are associated with a predisposition for resorptive lesions, and what is the initiating cause for the clastic activity afterwards (Okuda and Harvey, 1992; Shigayama et al., 1996). Grippo and Masi (1991) introduced the hypothesis that a variety of stresses on the teeth (tension and compression) caused by chewing, swallowing, clenching, eccentic loading and traumatogenic occlusion produce an electical potential difference between different portions of the teeth. This phenomenon the author termed as piezoelectric effect and stated that this electrical activity contributes to the electrochemical transfer of ions from the teeth into the saliva with later demineralization and erosion.

The present study was undertaken with the aim to describe enamel properties of transport and distribution of organic molecules in intact feline teeth and teeth affected with resorptive lesions.

\section{MATERIAL AND METHODS}

\section{Enamel sample preparation}

Two groups of enamel tissue samples were prepared and used as test material. The following experimental groups were formed according to the mode of sampling and tissue preparation:

Group I - consisted of 10 samples of intact enamel obtained from extracted intact teeth;

Group II - consisted of 10 samples of enamel tissue where visual resorption of enamel was observed.

Upper and lower jaws were obtained from a number of veterinary sources. All specimens were euthanized for reasons unrelated to this research. Details of age, gender, general health and dietary history were not known for most specimens. Teeth were extracted from the jaws and immediately after tooth extraction enamel tissue preparation was performed with the use of a watercooled machine (Kavo, Germany) with a rotation speed of 300,000 rpm (SuperTorque, 630 B, Kavo, Germany). Checking for the presence of dentine was made with a UV light. For each group of 10 samples preparations of enamel tissue were made. 
Enamel reduction was done on molars of both jaws. The size of the enamel preparations was approximately $3 \mathrm{~mm} \times 2 \mathrm{~mm} \times 2 \mathrm{~mm}$, where the $\mathrm{h}=2 \mathrm{~mm}$ is the cervico-occlusion dimension, $\mathrm{s}=2 \mathrm{~mm}$ vestibulo-oral dimension and $\mathrm{I}=2,5 \mathrm{~mm}$ thickness of the enamel. Observation on electronic paramagnetic (spin) resonance (EPR) Spectrometer was performed prior to the immersion in the organic spin marker solution in order to detect the presence of resonant signals. None of the samples showed the presence of resonant signals that might be a consequence of paramagnetic centers within.

The prepared samples could thus be used in further experiments with marker diffusion. In order to investigate the properties of the bilateral organic molecule diffusion in the enamel a water solution of an organic 4-Amino-Tempo spin marker was used. The concentration of the marker was $\mathrm{C}=0.02335 \mathrm{M}$ (250 $\mathrm{mL} \mathrm{H} \mathrm{H}_{2} \mathrm{O}+1 \mathrm{~g}$ Marker) and the number of spins $\mathrm{Ms}=7 \times 1016 / 0.0005 \mathrm{~cm}^{3}$. According to its structure the marker is similar to the toxins (or parts of toxins) of oral bacteria, as well as the detritus that can be found in the saliva and dental plaque. Its empirical formula is $\mathrm{C}_{9} \mathrm{H}_{19} \mathrm{~N}_{2} \mathrm{O}$, molecular weight 171.3. The oxygen within the nitrogen oxide radical has an unpaired electron $-0 \bullet$, and the electronic configuration 1s22s2ps2 has a spin $S=1 / 2$ and orbital moment $L=1$. Molecules that have an unpaired electron with $S$ spin are paramagnetic molecules which make paramagnetic centers in the diamagnetic matrix. Organic spins marker 4Amino-Tempo with a stable nitrogen oxide radical represents a paramagnetic molecule whose EPR spectrum has a characteristic triplet structure.

All samples were marked and immersed in the water solution of organic spin marker 4-Amino-Tempo. Monitoring time of the bilateral diffusion process was 30 days for all the samples.

\section{EPR Measurements}

The method of electronic paramagnetic (spin) resonance, representing a Spectroscopy method was used for the test. The experiment was carried out by an EPR Spectrometer Varian E-9 at the Institute for Nuclear Sciences in Vinča.

The quantity of diffused paramagnetic marker molecules was determined by measurements of the EPR enamel spectrum at different time intervals. The enamel samples (rinsed with distilled water and dried) were placed within a test tube in the EPR Spectrograph resonant cuvette. Within the range of the magnetic field of the resonant cuvette there was an interaction of the magnetic effects and paramagnetic molecules was detected by the appearance of a triplet spectrum. The spectrums are detected by the EPR Spectrometer and the integrals of the first derivative of the EPR spectrum have been calculated by a special computer program.

\section{RESULTS}

Analysis of the bilateral process of organic spin 4-Amin-Tempo marker diffusion in cats, enamel tissue was made by measurements of the first derivative of the EPR spectrum, of experimental groups in defined time intervals. Determination of the values of the integrals below the central absorption line was observed for all spectrums. Obtained results for both sample groups are presented in tables and figures. 
Results for GROUP I - INTACT ENAMEL

Values of integral I, the number of unbound molecules of markers that have diffused through the intact enamel over the entire volume of the sample Qmer, and the number of unbound molecules that have entered the sample with thickness I per surface $Q=Q m e r / s h$ for different diffusion times are presented in Table 1 . The number of diffused molecules of $Q$ marker in a sample of intact enamel is presented in Figure 1.

Table 1. Samples of the 1st Group - Intact enamel: Values of integrals, number of molecules in the entire volume of the sample and number of molecules that have entered a sample per unit of surface

\begin{tabular}{|c|c|c|c|}
\hline $\begin{array}{c}\text { Time } \\
\text { (hours) }\end{array}$ & Integral & $Q_{\text {mer }}$ & $\begin{array}{c}Q=Q_{\text {mer }} / \text { sh } \\
\left(1 / \mathrm{cm}^{2}\right)\end{array}$ \\
\hline \hline 2 & - & - & - \\
\hline 4 & - & - & - \\
\hline 7 & 2.43 & $4.2 \times 10^{14}$ & $42 \times 10^{14}$ \\
\hline 10 & 3.74 & $5.6 \times 10^{14}$ & $56 \times 10^{14}$ \\
\hline 14 & 3.66 & $5.6 \times 10^{14}$ & $56 \times 10^{14}$ \\
\hline 16 & 4.05 & $6.1 \times 10^{14}$ & $61 \times 10^{14}$ \\
\hline 18 & 4.59 & $6.8 \times 10^{14}$ & $68 \times 10^{14}$ \\
\hline 21 & 4.17 & $6.2 \times 10^{14}$ & $62 \times 10^{14}$ \\
\hline 23 & 3.82 & $5.8 \times 10^{14}$ & $58 \times 10^{14}$ \\
\hline 25 & 4.53 & $6.6 \times 10^{14}$ & $66 \times 10^{14}$ \\
\hline 28 & 4.13 & $6.2 \times 10^{14}$ & $62 \times 10^{14}$ \\
\hline 30 & 4.95 & $7.2 \times 10^{14}$ & $72 \times 10^{14}$ \\
\hline
\end{tabular}

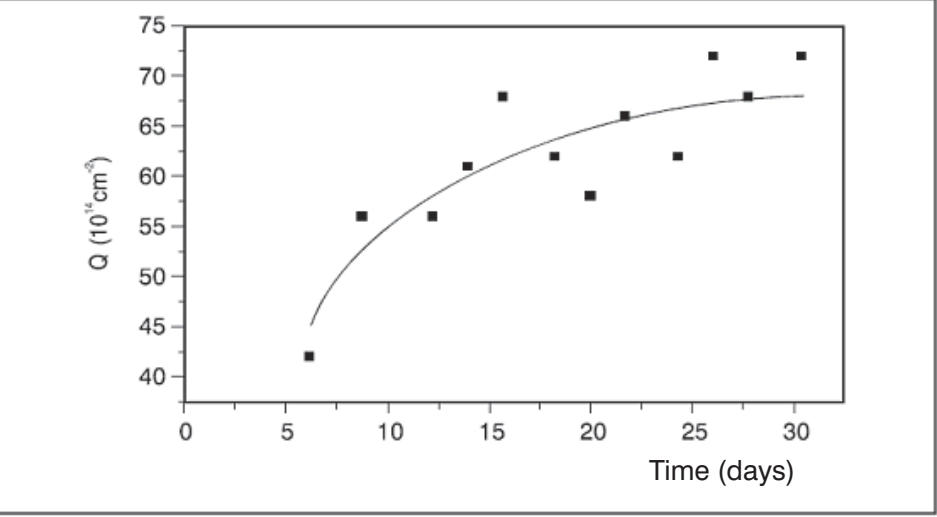

Figure 1. Number or unbound marker molecules that have entered the intact enamel, thickness $I=0.15 \mathrm{~cm}$, per unit of sample surface subject to diffusion time 
Acta Veterinaria (Beograd), Vol. 61, No. 5-6, 653-662, 2011.

Results for GROUP II -NON-INTACT ENAMEL

Interprysmatic spaces of experimental teeth were accessible to imbibition by different agents from the environment, before the beginning of the experiment while still in the cat's mouth. The marker diffusion parameters in the old non-intact enamel are presented in Table 2, and the dependence of the number of diffused molecules on time of diffusion is presented on Figure 2.

Table 2. Samples of the 3rd Group -non-intact enamel: Values of integrals, number of molecules in the entire volume of the sample and number of molecules that have entered a sample per unit of surface

\begin{tabular}{|c|c|c|c|}
\hline $\begin{array}{c}\text { Time } \\
\text { (hours) }\end{array}$ & Integral & $Q_{\text {mer }}$ & $\begin{array}{c}\text { Q=Qmer } \\
\left(1 / \mathrm{cm}^{2}\right)\end{array}$ \\
\hline \hline 2 & 1.07 & $5 \times 10^{14}$ & $45.5 \times 10^{14}$ \\
\hline 4 & 1.66 & $5.6 \times 10^{14}$ & $50.9 \times 10^{14}$ \\
\hline 7 & 2.01 & $6.3 \times 10^{14}$ & $57.3 \times 10^{14}$ \\
\hline 10 & - & - & - \\
\hline 14 & 2.43 & $6.6 \times 10^{14}$ & $60.0 \times 10^{14}$ \\
\hline 16 & 2.37 & $6.5 \times 10^{14}$ & $59.1 \times 10^{14}$ \\
\hline 18 & 3.17 & $7.5 \times 10^{14}$ & $68.2 \times 10^{14}$ \\
\hline 21 & 2.95 & $7.0 \times 10^{14}$ & $63.6 \times 10^{14}$ \\
\hline 23 & 2.91 & $7.0 \times 10^{14}$ & $63.6 \times 10^{14}$ \\
\hline 25 & 2.64 & $6.7 \times 10^{14}$ & $60.9 \times 10^{14}$ \\
\hline 28 & 2.84 & $6.9 \times 10^{14}$ & $62.7 \times 10^{14}$ \\
\hline 30 & 2.74 & $6.8 \times 10^{14}$ & $61.8 \times 10^{14}$ \\
\hline
\end{tabular}

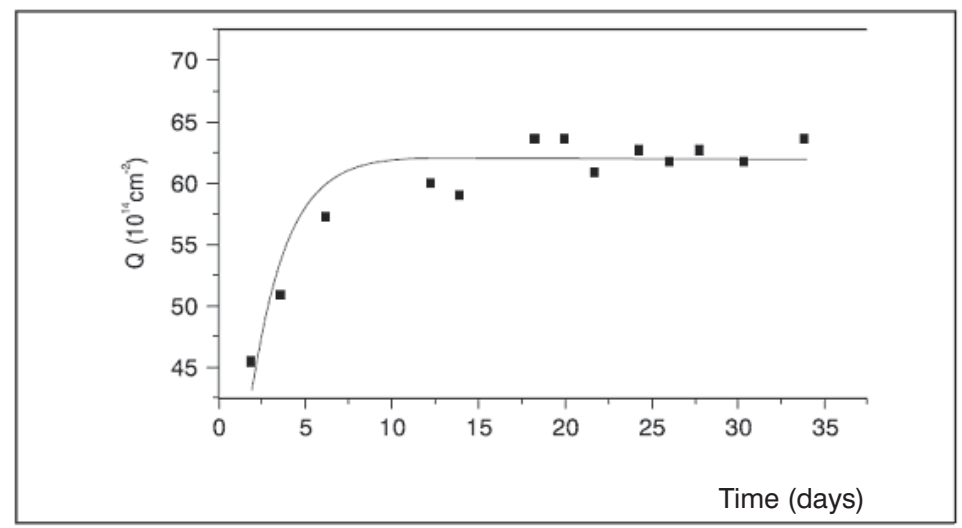

Figure 2. Number or unbound marker molecules that have entered the non-intact enamel, thickness $I=0.3 \mathrm{~cm}$, per unit of sample surface subject to diffusion time 
The experimentally determined dependence of the number of diffused marker molecules in the enamel tissue for a sufficient diffusion time may be approximated by the formula:

$$
\mathrm{Q}=\operatorname{No} 1(1-8 / \pi 2 \varphi-\pi 2 \mathrm{Dt} / / 2)(4)
$$

where $I$ = sample thickness, No - number of particles and D - diffusion coefficient.

Full lines on figures 1, 2 and 8 represent the dependence (4) adjusted to the experimental value.

The saturation value of the number of diffused molecules and the diffusion parameters at a temperature $\mathrm{t}=17^{\circ} \mathrm{C}$ are presented on Table 3 .

Table 3. Saturation value of the number of diffused marker molecules and diffusion coefficient at a temperature of $t=17^{\circ} \mathrm{C}$

\begin{tabular}{|c|c|c|c|c|c|}
\hline Samples & $\mathrm{I}(\mathrm{cm})$ & $\mathrm{s}(\mathrm{cm})$ & $\mathrm{h}(\mathrm{cm})$ & $\mathrm{N}_{\mathrm{o}} \mathrm{l}\left(\mathrm{cm}^{-2}\right)$ & $\mathrm{D}\left(\mathrm{cm}^{2} \mathrm{~s}^{-1}\right)$ \\
\hline \hline$(1)$ & 0.15 & 0.20 & 0.50 & $69.3^{\prime} 10^{14}$ & $3.0^{\prime} 10^{-9}$ \\
\hline$(3)$ & 0.30 & 0.20 & 0.55 & $61.7^{\prime} 10^{14}$ & $4.7^{\prime} 10^{-8}$ \\
\hline
\end{tabular}

\section{DISCUSSION}

Organic molecules of the 4-Amino-Tempo spin marker diffused through the enamel tissue thanks to its molecular structure and high reactivity of the nitrogen oxide radical. The bilateral process of marker diffusion that is happening in the enamel tissue is characterized by the concentration of diffused molecules and diffusion coefficient. Saturation of diffused marker molecules occurred after 3-4 weeks, which is also followed by the same saturation concentration of the diffused marker molecules:

$$
\text { NoIG }=0.46 \times 10^{17} \mathrm{~cm}^{-3} \text { INTACT ENAMEL }
$$

and diffusion coefficient:

$$
D I G=3.0 \times 10^{9} \mathrm{~cm}^{2} \mathrm{~S}-1 \mathrm{t}=17^{\circ} \mathrm{C}
$$

Contrary to the findings on these sample tissues the reduced enamel tissues which were exposed to oral conditions for a long time had a smaller saturation value of the concentration of diffused marker molecules.

$$
\text { NoSIG }=0.21 \times 10^{17} \mathrm{~cm}^{-3} \text { (NON-INTACT ENAMEL) }
$$

Marker molecules appeared after 10 days, showed a significantly higher diffusion coefficient:

$$
\text { DSRG }=4.7 \times 10^{8} \mathrm{~cm}^{2} \mathrm{~s}^{-1}, \mathrm{t}=17^{\circ} \mathrm{C}
$$

Faster diffusion and penetration of organic molecules into the non-intact enamel tissue indicates the harmful effects of leaving damaged enamel. Monitoring the diffusion process oscillations of diffused marker molecules number around the monotonous dependence of their concentration on the time and thickness of the reduction indicates the process of binding the marker molecules into the enamel tissue. One of such processes could be the 
Acta Veterinaria (Beograd), Vol. 61, No. 5-6, 653-662, 2011.

Zivković $\mathrm{R}$ et al.: Identifying enamel diffusion properties

in feline teeth affected with resorptive lesions

substitution of ions from the crystal grid of the apatite by an $\mathrm{N}-\mathrm{O}$ ion from the marker molecule. The available reference data on the properties of diffusion in the enamel (Borggreven, 1980; Chick and Waters 1963; Dibdin, 1972; Kambara and Konshi, 1977) can only be roughly compared. Analyses of the diffusion process of water, sodium and manganese in the enamel tissue represent a unilateral diffusion processes, whereas diffusion of the organic spin marker 4-Amino-Tempo is the result of a bilateral diffusion process (Tihaček-Šojć, 2005). The main elements of the inorganic component of the enamel tissue are found in the form of apatite crystals. The apatite crystals are hexagonally shaped, with an average size of $160 \times 40 \times 25 \mathrm{~nm}$. The crystal size depends on the crystallization rate. The apatite crystals in the enamel prism are ten times greater, on the average, than the crystals in the dentine and bones, which is caused by a slower rate of development of the enamel tissue. Diffusion inside the crystal structures is possible in a form of several different mechanisms such are mechanisms of substitution, vacancy, and interstitial and intrastitial mechanisms (Figures 3, 4, 5, and 6).

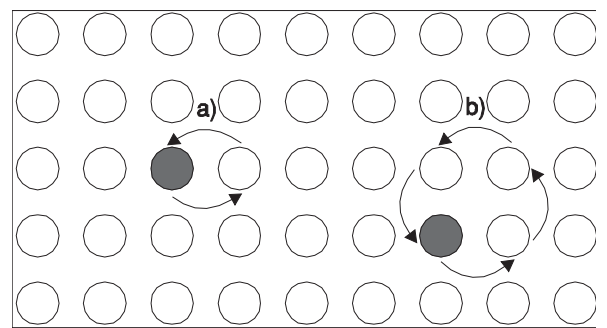

Figure 3. Substitution mechanism of diffusion

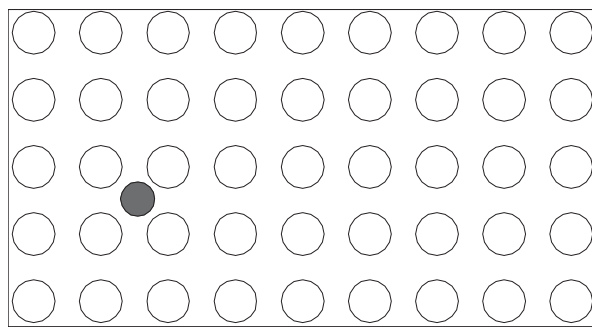

Figure 5. Interstitial mechanism of diffusion

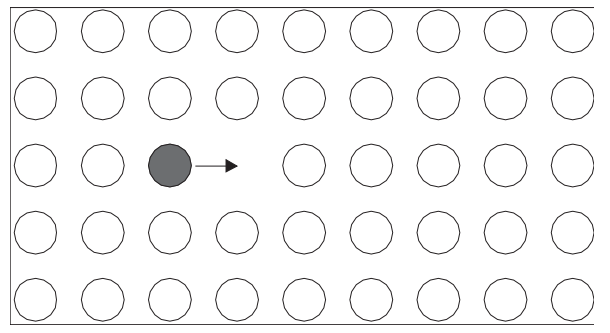

Figure 4. Vacancy mechanism of diffusion

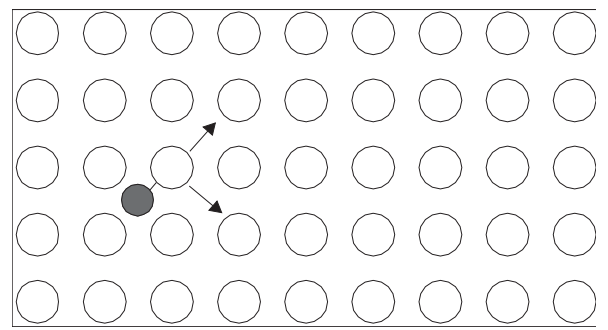

Figure 6. Intrastitial mechanism of diffusion

Which one of the described mechanisms is present in the diffusion process inside the feline enamel crystal grid is not yet clear. However, it may be speculated that feline enamel crystal grid is showing imperfection with resultant increased diffusion. As stated in the literature, teeth experience mechanical deformation many times a day during static and dynamic conditions (Grippo and Masi, 1991; 
Gracis and Orsini 1998; Lemic et al., 2006; Zivkovic et al., 2010). Resultant succession of tension and compression stresses and tooth displacement during occlusal loading might lead to breaking away of dental hard tissues. Excessive tensile forces disrupt the chemical bonds between the hydroxiapatite crystals resulting in the loss of tooth substance with initial micro fractures forming on the tooth surface.

The results obtained from this study concerning diffusion of non-intact enamel might confirm that there is a changed local environment around the susceptible teeth. Such a situation contributes to the transfer of ions and organic molecules from the teeth into the saliva and vice versa, with resultant dissolution of teeth and creating concavities in the structure of the tooth. Also, an alternate succession of tensile and compressive stresses leads to focal ischemia, biochemical alterations and subsequent resorptions. Recent studies of Muzylak et al. $(2006,2007)$ revealed that hypoxic conditions and local hypoxia in the tooth environment may play a role in the pathogenesis of feline dental resorptive lesions. Harvey et al. (2004) also speculated that either event, tearing of the periodontal ligament collagen fibers or exposing the rough cellular pre-cementum as a result of cement microcracs could stimulate a local microscopic concentration of cytokines. Subsequently, elevation in cytokines concentration attracts stem cells and initiates the resorptive process.

In conclusion this study provides data about diffusion process through intact and damaged enamel tissue. The results indicate that damaged enamel is prone to greater bilateral diffusion, leading to continual disruption of enamel structure. Also, teeth that are subjected to occlusal stress are at greater risk of destruction because micro fractures produce disarrangements in feline dental tissues diffusion homeostasis. The relationship between these features with feline dental resorptive lesions requires further studies.

Address for correspondence:

Aleksandra Milić Lemić

Clinic for Prosthetic Dentistry, School of Dentistry

University of Belgrade

Rankeova 4

11000 Belgrade, Serbia

E-mail: saskam@eunet.rs

\section{REFERENCE}

1. Borggreven JMPM, Driessens FCM, van Dijk JWE, 1980, Diffusion through bovine tooth enamel as related to the water structure in its pores, Arch Oral Biol, 25, 345-8.

2. Chick AO, Waters NE, 1963, Membrane potentials in teeth: Application of some common anions to enamel, J Dent Res, 42, 4, 934-42.

3. DeLaurier A, Boyde A, Horton MA, Price JS, 2006, Analysis of the surface characteristics and mineralization status of feline teeth using scanning electron microscopy, $J$ Anat, 209, 655-69.

4. DeLaurier $A$, Boyde $A$, Jackson $B$, Horton MA, Price JS, 2009, Identifying early osteoclastic resorptive lesions in feline teeth: a model for understanding the origin of multiple idiopathic root resorption, J Periodont Res, 44, 248-57.

5. Dibdin $\mathrm{GH}, 1972$, The stability of water in human dental enamel studied by proton nuclear magnetic resonance, Arch Oral Biol, 17, 433-7. 
6. Gracis $M$, Orsini $P, 1998$, Treatment of traumatic dental displacement in dogs: six cases of lateral luxation. J Vet Dent; 15, 2, 65-72.

7. Grippo JO, Masi JV, 1991, Role of biodental engineering factors (BEF) in the etiology of root caries, $J$ Esthet Dent, 3, 2, 71-6.

8. Harvey CE, Orsini P, McLahan C, Schuster C, 2004, Mapping of the radiographic central point of feline dental resorptive lesions, $J$ Vet Dent, 21, 1, 18-21.

9. Ingham KE, Gorrel C et al., 2001, Prevalence of odontoclasitc resorptive lesions in a population of clinically healthy cats, $J$ Small Anim Pract, 42, 439-43.

10. Kambara M, Konshi K, 1977, Study on the ion permeability of human dental enamel with special reference to an electrochemical approach, J Osaka Dental Univ, 11, 48-57.

11. Lemić A, Tihaček Šojic Lj, Ilić J, Živkovic R, 2006, Computational modeling of specific biological structures behavior, Acta Veterinaria (Beograd), 56, 4, 367-74.

12. Muzylak M, Price JS, Horton MA, 2006, Hypoxia induces giant osteoclast formation and extensive bone resorption in the cat, Calcif Tissue Int, 79, 169-77.

13. Muzylak M, Arnett TR, Price JS, Horton MA, 2007, The in vitro effect of $\mathrm{pH}$ on osteoclasts and bone resorption in the cat: implications for the pathogenesis of FORL, $J$ Cell Physiol, 213, 144-50.

14. Okuda A, Harvey CE, 1992, Etiopathogenesis of feline dental resorptive lesions, Vet Clin North Am Small Anim Pract, 22, 1385-404.

15. Reichart PA, Durr UM, Triadan H, Vickendey G, 1984, Periodontal disease in the domestic cat. A histopathologic study, J Periodontal Res, 19, 67-75.

16. Reiter AM, Mendoza KA, 2002, Feline odontoclastic resorptive lesions: an unsolved enigma in veterinary dentistry, Vet Clin North Am Small Anim Pract, 32, 791-837.

17. Roux P, Berger $M$ et al., 2005, Observations of the periodontal ligament and cementum in cats with dental resorptive lesions, $J$ Vet Dent, 22, 2, 74-85.

18. Schlup $D$, Stich $H, 1982$, Epidemiological and morphological investigations of teeth in the cat Morphological investigations of the neck lesions, Kleintier Praxis, 27, 179-88.

19. Schneck GW, Osborn JW, 1976, Neck lesions in the teeth of cats, Vet Rec, 99, 100.

20. Shigayama Y, Grove TK, Strayhorn C et al, 1996, Expression of adhesion molecules during tooth resorption in feline teeth: a model system for aggressive osteoclastic activity, J Dent Res, 75, 1650-7.

21. Tihaček-Šojić $L j, 2005$, Extent of diffusion of organic molecules in the enamel tissue of dogs, Acta Veterinaria (Beograd), 55, 1, 53-68.

22. Von Arx T, Schawalder P, Ackermann M et al., 2009, Human and feline invasive cervical resorptions: The missing link? - Presentation of four cases, J Endodont , 35, 6, 904-13.

23. Zivkovic R, Milic Lemic A, Tihacek Sojic LJ, Ilic J, 2010, Biomechanical aspect of feline dental resorptive lesion formation, Acta Veterinaria (Beograd), 60, 2-3.

\title{
IDENTIFIKOVANJE KARAKTERISTIKA DIFUZIJE KROZ GLEĐNO TKIVO ZUBA MAČKE OŠTEĆENOG RESORPTIVNIM PROCESOM
}

\author{
ŽIVKOVIĆ R, TODOROVIĆ A, TIHAČEK ŠOJIĆ LJILJANA i MILIĆ LEMIĆ ALEKSANDRA
}

\section{SADRŽAJ}

U patogenezi dentalnih resorptivnih lezija u mačaka pominju se različiti etiološki faktori kao što su oboljenja parodontalnih tkiva, faktori načina ishrane, mehaničko opterećenje, defekti nastali u toku razvoja zuba i virusna oboljenja. Ni za jedan od navedenih faktora do sada nije potvrđeno da je direktan uzročnik lezija. 
Nedavno je objavljeno da je gleđ u mačaka na gleđno-cementnoj granici značajno tanja od ostale gleđi, kao i da su gleđ i dentin tog područja mnogo manje mineralizovani nego na ostalim delovima zuba. Ipak nije potvrđeno da li postoje i posebni anatomski delovi zuba koji imaju predispoziciju za nastajanje resorptivnih lezija i šta je inicijalni faktor za kasnije aktiviranje odontoklasta.

Istraživanje je sprovedeno sa ciljem da se ispita distribucija i transport organskih molekula intaktne gleđi zuba mačke i gleđi koja je zahvaćena resorptivnim procesom.

Rezultati istraživanja prikazuju da je oštećena gleđ podložnija intenzivnijem bilateralnom procesu difuzije, koja dovodi do kontinualnog oštećivanja strukture gleđi. Zubi koji su izloženi okluzalnom opterećenju su takođe pod većim rizikom od propadanja jer mikropukotine koje nastaju usled koncentracije napona uzrokuju poremećaj homeostaze dentalnih tkiva. Utvrđivanje povezanosti faktora difuzije i mehaničkog opterećenja zahteva dodatna istraživanja. 